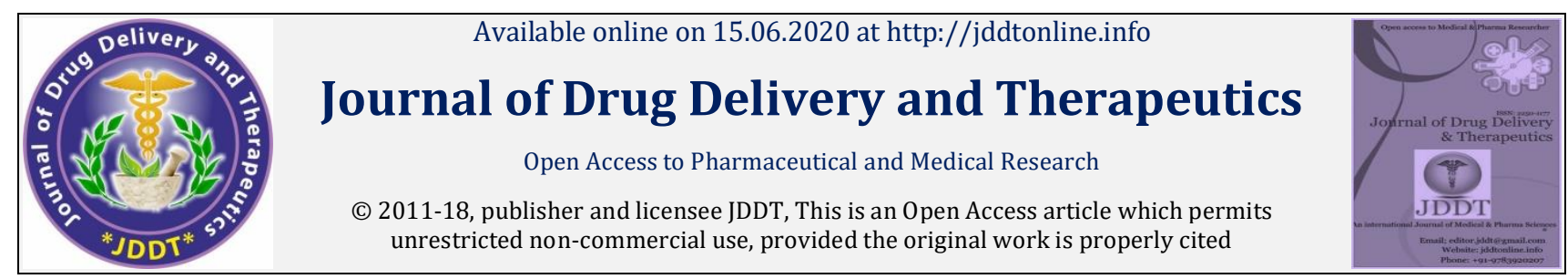

Open $\odot$ Access

Research Article

\title{
Development and Evaluation of Gastro-retentive Floating Tablet of Rilpivirine Hydrochloride for the Treatment of HIV
}

\author{
Dipali Trivedi*, Arti Majumdar, Neelesh Malviya
}

Smriti College of Pharmaceutical Education, Indore (M.P.), India

\begin{abstract}
Besides enormous improvements in drug delivery, oral route has been highly and effectively utilized route of administration. Floating drug delivery that is also known to be low density system is advancement in the class of gastro-retentive drug delivery system. In the present research work, floating drug delivery of Rilpivirine hydrochloride was developed by overcoming various limitations and troubles associated with the drug including poor absorption in intestinal $\mathrm{pH}$ and degradation when comes in contact with higher $\mathrm{pH}$ environment. [2] Prepared formulations were evaluated for various parameters like friability, hardness, thickness, drug content analysis, floating properties and in-vitro drug release study. Based on the evaluation, concluded that floating drug delivery system is a non-toxic as well as cost-effective technique for the rationale of enhancing bioavailability and absorption of poorly water soluble drugs. The improvement in gastric residence time is a clear sign. It can be able to use in the future for more acidic soluble drugs to enhance solubility and absorption.
\end{abstract}

Keywords: Floating drug delivery, gastric residence time, Rilpivirine, effervescent, NNRTI.

Article Info: Received 27 March 2020; Review Completed 19 May 2020; Accepted 24 May 2020; Available online 15 June 2020

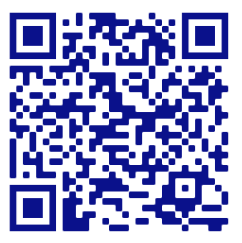

Cite this article as:

Trivedi D, Majumdar A, Malviya N, Development and Evaluation of Gastro-retentive Floating Tablet of Rilpivirine Hydrochloride for the Treatment of HIV, Journal of Drug Delivery and Therapeutics. 2020; 10(3-s):43-46 http://dx.doi.org/10.22270/jddt.v10i3-s.4115

*Address for Correspondence:

Dipali Trivedi, Smriti College of Pharmaceutical Education, Indore (M.P.), India

\section{INTRODUCTION:}

A virus that devastate the immune system of the body and causes Acquired Immuno Deficiency Syndrome (AIDS) is Human Immuno-deficiency Virus (HIV). Number of drugs are investigated to be anti-HIV.[1] The drugs like Rilpivirine appears to be most appropriate non- nucleoside reverse transcriptase inhibitor for the treatment of HIV-1 in adults because it has better tolerability which leads to less drug discontinuation and fewer side effects as compared to other NNRTIs.

The main objective of the research work was to design a floating drug delivery system for Rilpivirine hydrochloride. The solubility and systemic absorption of Rilpivirine is $\mathrm{pH}$ dependent. It is demonstrated by an increased bioavailability in an acidic environment. [2] To improve the absorption of Rilpivirine by preventing the drug from alkaline environment, floating tablet was prepared.

\section{MATERIALS AND METHODS:}

Materials: Rilpivirine hydrochloride was received as a gift sample from Cipla Research and Development, Mumbai. HPMC, Sodium bicarbonate, crospovidone and microcrystalline cellulose were received from Smriti College of Pharmaceutical Education, Indore. Further chemicals used during formulation were analytical grade.

\section{Method:}

\section{Preparation of Tablets:}

The active ingredient and excipients were weighed accurately and powder blend was directly compressed into tablet with the help of tablet punching machine consisting of $25 \mathrm{mg}$ of Rilpivirine hydrochloride. 
Table 1: Composition of Floating Tablet

\begin{tabular}{|l|c|c|c|c|c|c|}
\hline Composition & F1(mg) & F2(mg) & F3(mg) & F4(mg) & F5(mg) & F6(mg) \\
\hline Rilpivirine HCl & 25 & 25 & 25 & 25 & 25 & 25 \\
\hline HPMC & 80 & 80 & 80 & 80 & 80 & 80 \\
\hline Crospovidone & 65 & 65 & 65 & 65 & 65 & 65 \\
\hline Microcrystalline cellulose & 70 & 70 & 85 & 70 & 70 & 70 \\
\hline Magnesium stearate & 25 & 25 & 25 & 25 & 25 & 25 \\
\hline Sodium bicarbonate & 60 & 50 & 40 & 40 & 35 & 25 \\
\hline Citric acid & 15 & 25 & 20 & 35 & 40 & 50 \\
\hline Lactose & 10 & 10 & 10 & 10 & 10 & 10 \\
\hline Total weight & $\mathbf{3 5 0}$ & $\mathbf{3 5 0}$ & $\mathbf{3 5 0}$ & $\mathbf{3 5 0}$ & $\mathbf{3 5 0}$ & $\mathbf{3 5 0}$ \\
\hline
\end{tabular}

\section{Evaluation of prepared tablets:}

\section{Weight variation:}

It was carried out to ensure the proper amount of drug in each tablet. 20 tablets were weighed individually with the help of analytical balance. The average weight was calculated and the percent weight variation was calculated with the help formula.

$\%$ Weight Variation $=$ (Individual weight - Average weight)/ Average weight $x 100$

\section{Hardness:}

The hardness of the tablet was determined with the help of Monsanto hardness tester and expressed in $\mathrm{kg} / \mathrm{cm}^{2}$.

\section{Diameter and thickness:}

The diameter and the thickness of the tablet was measured with the help of vernier caliper and expressed in $\mathrm{mm}$.

\section{Friability:}

Tablets equivalent to $6.5 \mathrm{gm}$ were weighed and placed into the apparatus. They were exposed to rolling and repeated shocks as they fall from six inches in each turn within the apparatus. After 4 minutes or 100 revolutions, the tablets were reweighed and the loss due to abrasion was measured. Not more than $1 \%$ of the weight of the tablets is acceptable.

\section{$\%$ Friability $=\left(W_{1}-W_{2}\right) / W_{1} \times 100$}

Here, $W_{1}$ is the initial weight of tablet and $W_{2}$ is the final weight of tablet.

\section{Floating properties of prepared formulations:}

The formulation was tested for floating properties like floating lag time and total floating time. Tablets were placed in a $100 \mathrm{ml}$ beaker containing $0.1 \mathrm{~N} \mathrm{HCL}(1.2 \mathrm{pH})$. The time required raising the tablet to the surface and show buoyancy was taken as the floating lag time. The total time interval of the tablet to float on the surface was taken as total floating time.

\section{Drug content:}

Tablets were randomly selected and crushed into mortar pestle. A suitable quantity of powder was extracted with 100 $\mathrm{ml}$ of $0.1 \mathrm{~N} \mathrm{HCl}$. This solution was filtered and analyzed under UV-spectrophotometer (Shimadzu 1800) at $315 \mathrm{~nm}$.

\section{In-vitro drug release:}

The drug release from the Rilpivirine hydrochloride floating tablets was investigated in a USP-II (paddle) apparatus. At predestined time intervals, aliquot were withdrawn and then analyzed under UV Spectrophotometer at $\lambda$ max at $315 \mathrm{~nm}$.

RESULTS:

Table 2: Pre-compression studies of formulated floating tablets

\begin{tabular}{|c|c|c|c|c|c|}
\hline $\begin{array}{l}\text { Formulation } \\
\text { Code }\end{array}$ & $\begin{array}{l}\text { Bulk density } \\
\text { (gm/mL) } \pm \text { SD }\end{array}$ & $\begin{array}{c}\text { Tapped } \\
\text { Density } \\
(\mathrm{gm} / \mathrm{mL}) \pm \mathrm{SD}\end{array}$ & $\begin{array}{c}\text { Carr's Index } \\
\text { (\%) } \pm \text { SD }\end{array}$ & $\begin{array}{l}\text { Hausner's } \\
\text { Ratio }\end{array}$ & 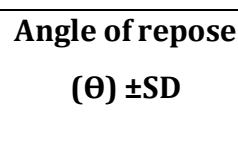 \\
\hline F1 & $0.412 \pm 0.009$ & $0.612 \pm 0.014$ & $12.7 \pm 0.08$ & 1.48 & $25.55 \pm 0.91$ \\
\hline F2 & $0.317 \pm 0.01$ & $0.367 \pm 0.02$ & $13.24 \pm 0.13$ & 1.15 & $22.33 \pm 0.88$ \\
\hline F3 & $0.374 \pm 0.006$ & $0.542 \pm 0.018$ & $11.81 \pm 0.18$ & 1.44 & $25.55 \pm 0.86$ \\
\hline F4 & $0.296 \pm 0.03$ & $0.320 \pm 0.03$ & $14.65 \pm 0.06$ & 1.08 & $21.12 \pm 0.54$ \\
\hline F5 & $0.296 \pm 0.03$ & $0.391 \pm 0.07$ & $13.63 \pm 0.04$ & 1.32 & $26.71 \pm 0.46$ \\
\hline F6 & $0.327 \pm 0.03$ & $0.389 \pm 0.04$ & $14.56 \pm 0.04$ & 1.18 & $25.07 \pm 0.41$ \\
\hline
\end{tabular}


TABLE 3:Post-compression studies of formulated floating tablets

\begin{tabular}{|c|c|c|c|c|c|c|c|}
\hline $\begin{array}{l}\text { Batch } \\
\text { Code }\end{array}$ & $\begin{array}{l}\text { Thickness } \\
(\mathrm{mm}) \pm \mathrm{SD}\end{array}$ & $\begin{array}{c}\text { Hardness } \\
(\mathrm{Kg} / \mathrm{cm} 2) \\
\pm \mathrm{SD}\end{array}$ & $\begin{array}{c}\text { Friability } \\
\text { (\%) }\end{array}$ & $\begin{array}{c}\text { Weight } \\
\text { Variation } \\
(\%)\end{array}$ & $\begin{array}{l}\text { Floating } \\
\text { Lag time } \\
\text { (sec) }\end{array}$ & $\begin{array}{c}\text { Total } \\
\text { Floating } \\
\text { time (hrs) }\end{array}$ & $\begin{array}{c}\text { Drug } \\
\text { Content }(\%) \\
\pm \text { SD }\end{array}$ \\
\hline F1 & $3.23 \pm 0.76$ & $5.33 \pm 0.844$ & 0.53 & $2.5 \pm 0.661$ & 18 & 22 & $96.15 \pm 1.53$ \\
\hline F2 & $3.4 \pm 0.41$ & $5.41 \pm 1.21$ & 0.40 & $2.2 \pm 0.564$ & 19 & 26.04 & $97.25 \pm 1.71$ \\
\hline F3 & $3.36 \pm 0.449$ & $5 \pm 0.894$ & 0.65 & $3.5 \pm 0.776$ & 25 & 23 & $95.22 \pm 0.91$ \\
\hline F4 & $3.53 \pm 0.28$ & $4.83 \pm 1.329$ & 0.81 & $3.7 \pm 0.913$ & 10 & 24.10 & $93.17 \pm 2.76$ \\
\hline F5 & $3.51 \pm 0.41$ & $5.22 \pm 0.983$ & 0.47 & $3.1 \pm 0.852$ & 6 & 10 & $92.45 \pm 2.15$ \\
\hline F6 & $3.46 \pm 0.406$ & $5.16 \pm 2.56$ & 0.70 & $3.9 \pm 0.987$ & 4 & 4.05 & $93.27 \pm 0.98$ \\
\hline
\end{tabular}

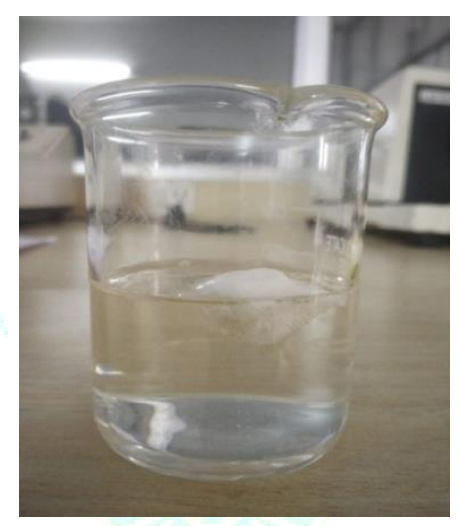

Figure 1: Floating Tablet

TABLE 4: Drug release profile of formulated floating tablets

\begin{tabular}{|c|c|c|c|c|c|c|}
\hline \multirow{2}{*}{ Time (hrs) } & \multicolumn{6}{|c|}{ Cumulative Drug Release of Prepared Formulation } \\
\cline { 2 - 7 } & Batch 1 & Batch 2 & Batch 3 & Batch 4 & Batch 5 & Batch 6 \\
\hline $0.5 \mathrm{hr}$ & $9.1 \pm 0.12$ & $9.3 \pm 1.6$ & $10.1 \pm 0.7$ & $11.1 \pm 1.1$ & $11.8 \pm 1.1$ & $15.4 \pm 0.7$ \\
\hline $1 \mathrm{hr}$ & $14.1 \pm 1.8$ & $13.3 \pm 1.4$ & $13.8 \pm 0.7$ & $14.1 \pm 1.4$ & $16.2 \pm 1.77$ & $18.4 \pm 1.5$ \\
\hline $2 \mathrm{hr}$ & $20.6 \pm 0.6$ & $21.2 \pm 2.7$ & $20.1 \pm 1.7$ & $19.2 \pm 0.8$ & $23.6 \pm 1.7$ & $25.4 \pm 0.75$ \\
\hline $3 \mathrm{hr}$ & $31.5 \pm 0.9$ & $33.6 \pm 2.2$ & $30.7 \pm 2.1$ & $28.1 \pm 1.8$ & $31.3 \pm 0.9$ & $37.9 \pm 0.86$ \\
\hline $4 \mathrm{hr}$ & $39.2 \pm 0.9$ & $41.8 \pm 1.9$ & $38.9 \pm 1.2$ & $37.5 \pm 0.8$ & $43.6 \pm 2.6$ & $42.9 \pm 2.31$ \\
\hline $5 \mathrm{hr}$ & $45.5 \pm 2.6$ & $49.6 \pm 1.1$ & $45.1 \pm 1.7$ & $43.1 \pm 1.1$ & $55.1 \pm 0.5$ & $55.2 \pm 1.82$ \\
\hline $6 \mathrm{hr}$ & $56.9 \pm 3.2$ & $54.9 \pm 1.3$ & $53.8 \pm 0.7$ & $51.7 \pm 2.2$ & $60.3 \pm 1.7$ & $61.6 \pm 0.12$ \\
\hline $18 \mathrm{hr}$ & $70.7 \pm 1.6$ & $76.7 \pm 1.4$ & $64.5 \pm 1.2$ & $72.8 \pm 2.9$ & $72.4 \pm 1.5$ & $79.5 \pm 0.14$ \\
\hline $20 \mathrm{hr}$ & $82.2 \pm 0.8$ & $87.7 \pm 1.9$ & $83.6 \pm 1.2$ & $80.4 \pm 2.3$ & $83.2 \pm 2.21$ & $85.2 \pm 0.91$ \\
\hline $24 \mathrm{hr}$ & $90.7 \pm 0.59$ & $94.8 \pm 0.81$ & $90.0 \pm 0.98$ & $89.9 \pm 0.84$ & $94.5 \pm 0.99$ & $97.6 \pm 1.51$ \\
\hline
\end{tabular}




\section{Dissolution study of formulated batches:}

The dissolution study of floating tablets were performed in $0.1 \mathrm{~N} \mathrm{HCl}(1.2 \mathrm{pH})$ and observed results are depicted in the graph (Figure 2).

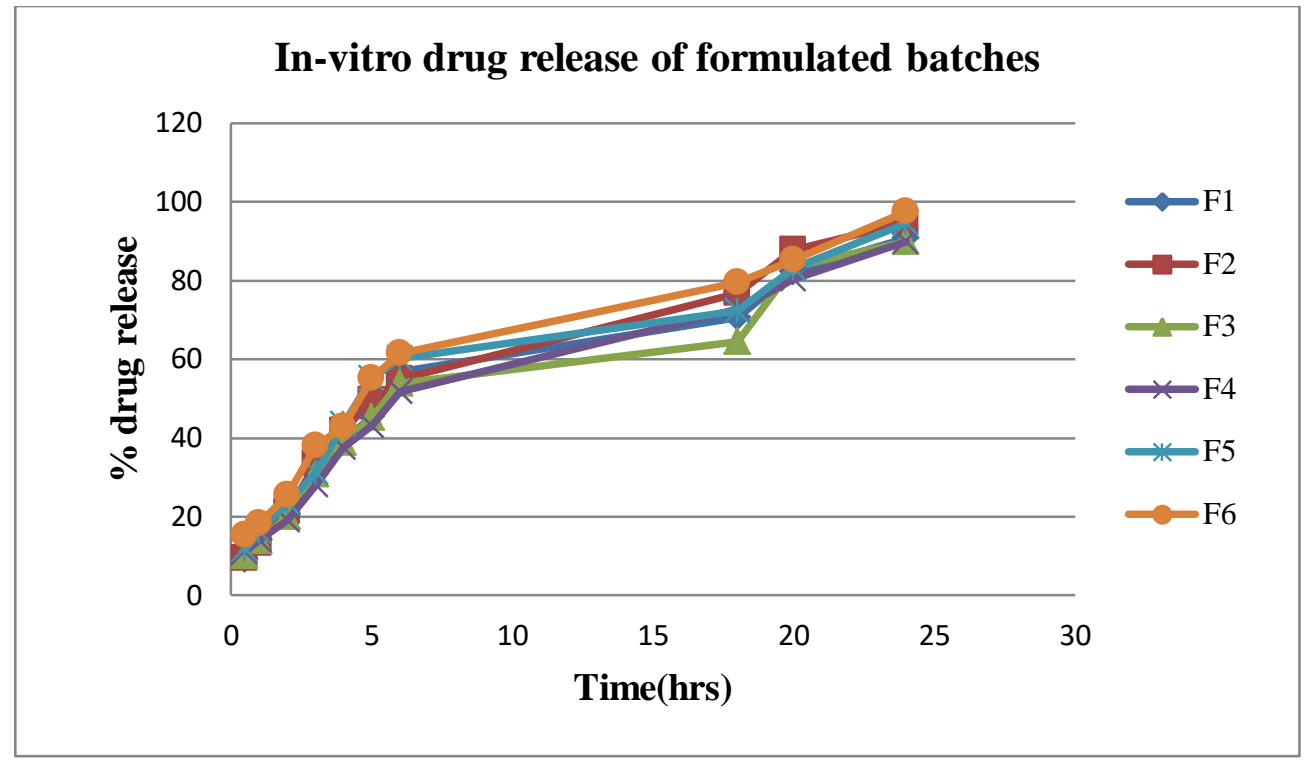

Figure 2: In-vitro drug release study

\section{DISCUSSION:}

In this research work, the effervescent floating tablets of Rilpivirine $\mathrm{HCl}$ were successfully formulated using citric acid and sodium bicarbonate as gas forming agent and HPMC as film forming polymer. The identification tests of Rilpivirine $\mathrm{HCl}$ drug sample was done with the help of UV analysis, melting point determination, solubility studies, and IR and DSC tests. The observations recorded were identical to the values reported in literature. The evaluations of prepared floating tablet reveal encouraging result, because the prolonged gastric residence time is an enhancement in bioavailability. The optimized batch (F2) gave the best result in terms of in-vitro drug release rate and floating duration ( $>24 \mathrm{hrs}$ ). Sodium bicarbonate and citric acid were used in the ratio of 2:1 in optimized batch (F2), the release rate of this formulation was gradual enough to prolong the drug delivery and absorbed in gastric fluid.

\section{REFERENCES:}

1. Reeves J, Doms R. Human Immuno-deficiency Virus. Journal of General Virology. 2002; 83(6):1253-1265.

2. Sharma M, Louis D. Rilpivirine: a new non-nucleoside reverse transcriptase inhibitor. Journal of Antimicrobial Chemotherapy. 2012; 68:250-256.
3. Bhatti A, Usman M, Kandi V. Current scenario of HIV/AIDS, treatment options, and major challenges with compliance to antiretroviral therapy. Cureus Publishing. 2016; 8(3):1-12.

4. Baumgartner S, Kristl J, Vrecer F. Optimization of floating matrix tablet and evaluation of their gastric residence time. International Journal of Pharmaceutics. 1999; 195(2000):125135.

5. Ansel $\mathrm{CH}$, Loyd V. Pharmaceutical dosage form and drug delivery system. International Journal of Pharmaceutical compounding. 9th edition, 2011.

6. Vyas SP, Khar R. Controlled Drug Delivery concepts and advances. $2^{\text {nd }}$ edition, 2012.

7. Dubey J, Verma N. Floating Drug Delivery System: A Review. International Journal of Pharmaceutical Science and Research. 2013; 4(8):2893-2899.

8. Tripathi J, Thapa P. A review on current state and future perspective on GRDDS. MDPI. 2019; 11(4):6-16.

9. Kommavarapu P, Sunkara M. Preparation and characterization of Rilpivirine solid dispersion with application of enhanced solubility and dissolution rate. Beni-Suef University Journal of Basic and Applied Sciences. , 2015; 4:2-4.

10. Ramesh, K, Micronization and formulation for improvement of rate of dissolution of Rilpivirine. Beni-Suef University Journal of Basic and Applied Sciences. 2015; 1-2. 